\title{
IMPACT OF THE USE OF EXISTING DITCH VECTOR DATA ON SOIL MOISTURE PREDICTIONS
}

\author{
*Janis Ivanovs, Toms Stals, Santa Kaleja \\ Latvian State Forest Research Institute 'Silava', Latvia \\ *Corresponding author’s email: janis.ivanovs@silava.lv
}

\begin{abstract}
Wet soils play an important role in hydrological, biological and chemical processes, and knowledge on their spatial distribution is essential in forestry, agriculture and similar fields. Digital elevation models (DEM) and various hydrological indexes are used to perform water runoff and accumulation processes. The prerequisite for the calculation of the hydrological indexes is the most accurate representation of the Earth's surface in the DEM, which must be corrected as necessary to remove surface artifacts that create a dam effect. In addition, different resolutions for DEM give different results, so it is necessary to evaluate what resolution data is needed for a particular study. The aim of this study is to evaluate the feasibility of using existing ditch vector data for DEM correction and the resulting implications for soil moisture prediction. Applied methodology uses a network of available ditch vectors and creates gaps in the overlapping parts of the DEM. The data were processed using open source GIS software QGIS, GRASS GIS and Whitebox GAT. Ditch vector data were obtained from JSC Latvian State Forests and the Latvian Geospatial Information Agency. The results show that by applying the bottomless ditch approach in forest lands on moraine deposits, depending on the accuracy of the ditch vector data, the values of the prediction of the soil wetness both increase and decrease. On the other hand, in forest lands on graciolimnic sediments it is visible that predicted soil wetness values increase in the close proximity of ditches. For forest lands on glaciofluvial and eolitic sediments there were no visible changes because of lack of ditches.
\end{abstract}

Key words: wet area maps, quaternary sediments, LiDAR.

\section{Introduction}

Open wetland areas are easily identified and mapped by orthophoto or satellite imagery, but are more difficult to identify in the forest under an enclosed tree canopy or near waterbodies and streams (Creed et al., 2003; Gregory et al., 1991). In Latvia, studies on the spatial distribution of wetland soils in forest lands have begun relatively recently (Ivanovs \& Lupikis, 2018) and so far have developed methods for deciphering wetlands on different types of geological sediments. For this purpose LiDAR (Light Detecting and Range) data maintained by the Latvian Geospatial Information Agency and Sentinel-2 multispectral satellites were used.

Information on the spatial distribution of wetlands is important for both scientific and management planning in areas such as forestry and agriculture (McNabb, Startsev, \& Nguyen, 2001). This information can help explain biological, hydrological, chemical, and other processes (Detenbeck et al., 1999). Hydromorphic soils have a lower bearing capacity than automorphic soils and are therefore more prone to disturbances such as compaction, rutting, etc. (Cambi et al., 2015; Mohtashami et al., 2017).

Digital terrain models and various hydrological indices are used to perform water runoff and accumulation processes (Robson, Beven, \& Neal, 1992). The prerequisite for calculating the hydrological indexes is the most accurate representation of the Earth's surface in the digital terrain model, which needs to be corrected to remove surface artifacts that produce a dam effect (Lidberg et al., 2017). In addition, different resolutions of the DEM (digital elevation model) give different results, so it is necessary to evaluate what resolution data is needed for a particular study (Dehvari \& Heck, 2013).

The aim of the study is to test the performance of the wet area detection algorithm under conditions using existing spatial data from ditches and natural drains. It is assumed that if the water flows to a ditch as a result of surface runoff modeling, it is automatically removed from the system. Improvements for methodology are necessary to avoid manual DEM corrections.

\section{Materials and Methods}

The study objects represent all the most popular Quaternary geological sediment types (Glaciolimnic, Gglacigenic, Glaciofluvial and Eolitic) and are dominated by forests on mineral and drained mineral soils. The study objects each cover an area of $9 \mathrm{~km}^{2}$, in the central part of which $1 \mathrm{~km}^{2}$ is used for the placement of plots. The buffer zone was created for the purpose of modeling the surface water runoff, thereby providing continuous calculation area for larger territory. Quaternary geological sediment data were obtained from the Quaternary sediment map at a scale of 1:200,000 (Meirons, 2002). The geospatial data of the forest stands were obtained from the JSC Latvian State Forests. The location of the research objects is shown in Figure 1. The DEM was obtained using laser scanning data maintained by the Latvian Geospatial Information Agency and the processing of geospatial data was performed in QGIS and GRASS GIS programs.

Digital elevation models were overlayed with existing ditch vector data which are maintained by 


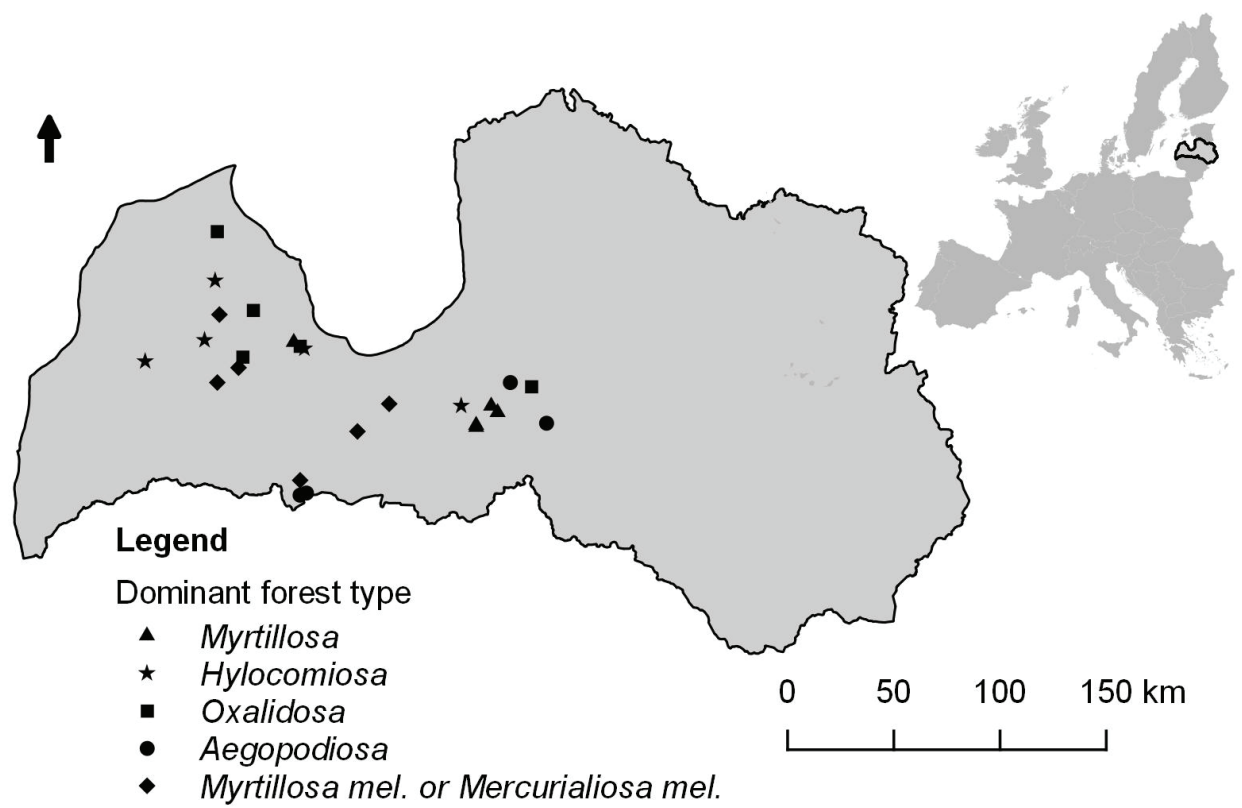

Figure 1. Location of research objects.

JSC Latvian State Forests and Latvian Geospatial Information Agency were thus cutting holes in the relief model. And during surface water runoff modelling on modified DEM's, surplus water was removed from the model through the holes in DEM.

The newly created DEM layers with a horizontal resolution of $2 \mathrm{~m}$ have been used to obtain 2 $\mathrm{m}$ horizontal resolution models of the surface slope, surface depressions, normalized height and SAGA moisture index data. The obtained indices characterizing the surface of the Earth were used to produce maps of soil moisture predictions based on previous research (Ivanovs \& Lupikis, 2018) and following formula:

if $(N=G L$ or $N=H,(\exp (2.522-1.226 *$

$\left.\left.S \_5 m-5.012 * N H \_2 m\right)\right) /(\exp (2.522-1.226 *$

$\left.\left.S \_5 m-5.012 * N H \_2 m\right)+1\right),(i f(N=$

$G\left(\exp \left(48.749 * D \_2 m-3.645\right)\right) /(\exp (48.749 *$

$\left.\left.D \_2 m-3.645\right)+1\right),($ if $(N=G F,(\exp (32.95-$

$2.788 * W \_2 m-63.565 * N H \_5 m-2.387 *$

$\left.\left.S \_5 m\right)\right) /\left(\exp \left(32.95-2.788 * W \_2 m-\right.\right.$

$\left.\left.63.565 * N H \_5 m-2.387 * S \_5 m\right)+1\right),(i f(N=$

$E,(\exp (96.576 * N D V I * F-93.506-2.437 *$

$\left.\left.N H \_m 2+1.651 * W \_2 m\right)\right) /(\exp (96.576 *$

$N D V I * F-93.506-2.437 * N H_{-} m 2+1.651 *$ W_2m +1$), 1 / 0))())))$,

where N - Quaternary sediment raster, G - Glacigenic sediments, GL - Glaciolimnic sediments, GF Glaciofluvial sediments, E - Eolitic sediments, H Organic sediments, $\mathrm{S}$ - raster of slope, D - raster of depressions, $\mathrm{NH}$ - normalized height raster, $\mathrm{W}$ - Saga wetness index, F - Forest cover (1 or null). Numbers by indices show necessary resolution.
To compare the results with and without effect of using existing ditch vector data, the soil moisture prediction rasters were compared with each other using raster calculator. Thus, resulted rasters indicate differences between both methods (Figure 2). Raster values leaning towards -1 indicate that prediction for the area is more wet than predicted using previous methodology and for values that are leaning towards +1 it's getting dry. The obtained results were compared by creating raster histograms. Raster data is presented as input data, which shows differences in predictions. The generated histograms are plotted on a logarithmic scale and indicate the number of cells that are leaning to one side or the other, predicting drier or wetter conditions, respectively.

\section{Results and Discussion}

The areas on the glacigenic, or moraine sediments have both areas where drier and wetter areas are formed according to the methodology tested in this study (Figure 2). In the close proximity of the ditches, soil wetness values have declined due to the elimination of local depressions. However, the soil wetness prediction values have increased in some areas and that may be due to a shift in the ditch vectors' locations relative to the location of the ditches in the LiDAR data or other conditions. A comparison picture of the results of the various methods gives a visual indication of the 'noise' around the wet areas. This noise is due to data processing in the preparation of input raster and resulted in a slight shift in wet areas.

The results for areas that represent the situation on glaciolimnic sediments are shown in Figure 3. It can be seen that, when ditch vector data is used for DEM 


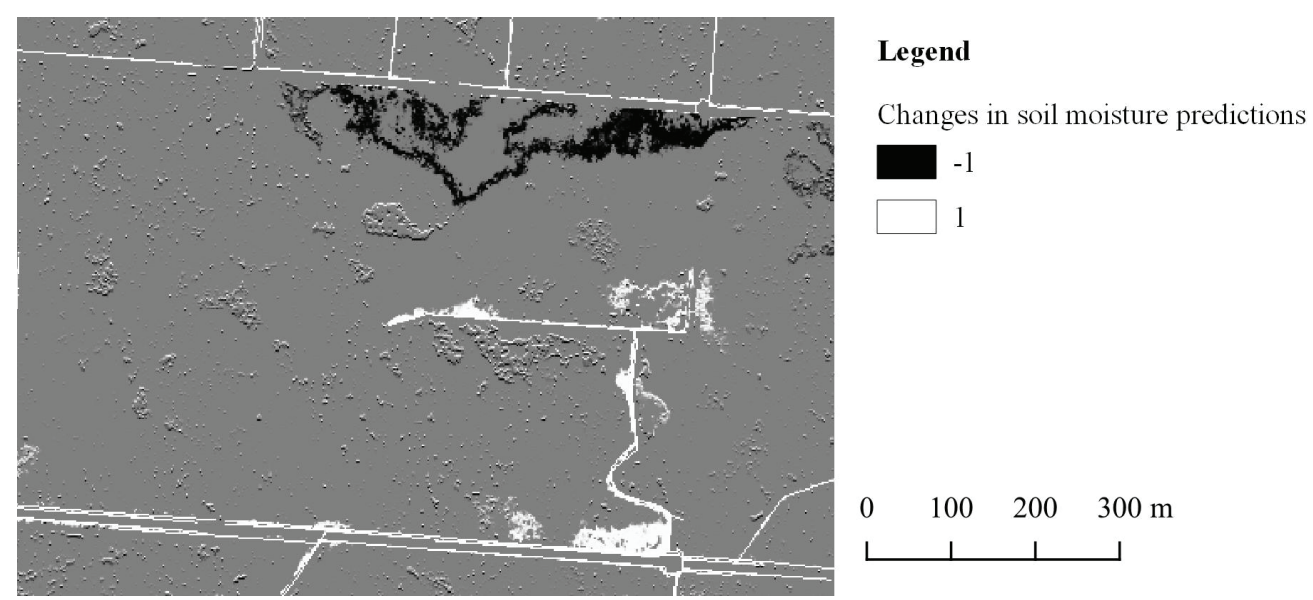

Figure 2. Soil wetness prediction changes on glacigenic sediments.

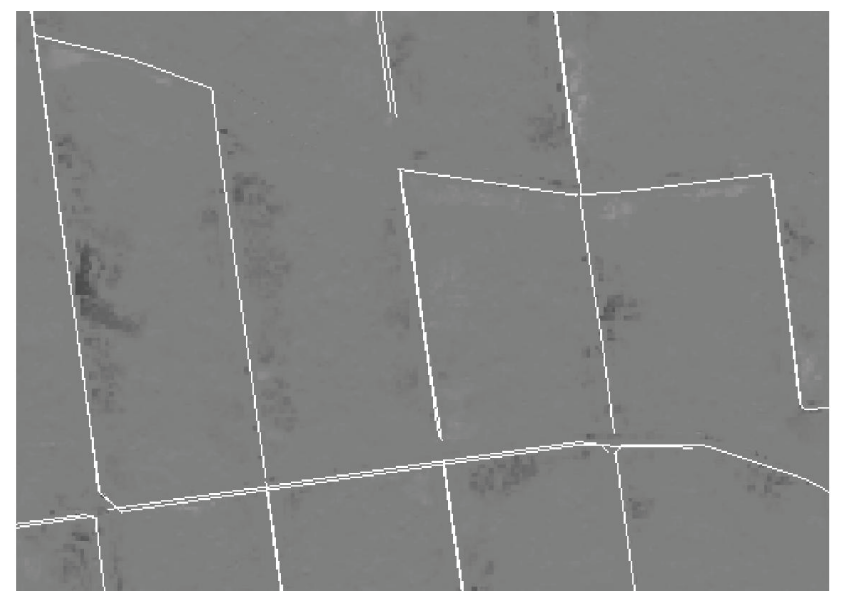

\section{Legend}

Changes in soil moisture predictions

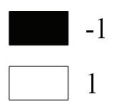

$0 \quad 100 \quad 200 \quad 300 \mathrm{~m}$

Figure 3. Soil wetness prediction changes on glaciolimnic sediments.

correction, higher soil moisture is predicted in areas adjacent to ditches. No changes have been observed in areas further from the ditches. The effect of this ditch proximity is explained by the input raster files that are used to predict soil moisture on glaciolimic sediments. A significant influence on soil moisture distribution is coming from normalized height raster, which indicates local elevation changes. By their nature, ditches are considered to be locally lower terrain. If ditch elevation information is removed from the local elevation map, other adjacent areas should become locally lower.
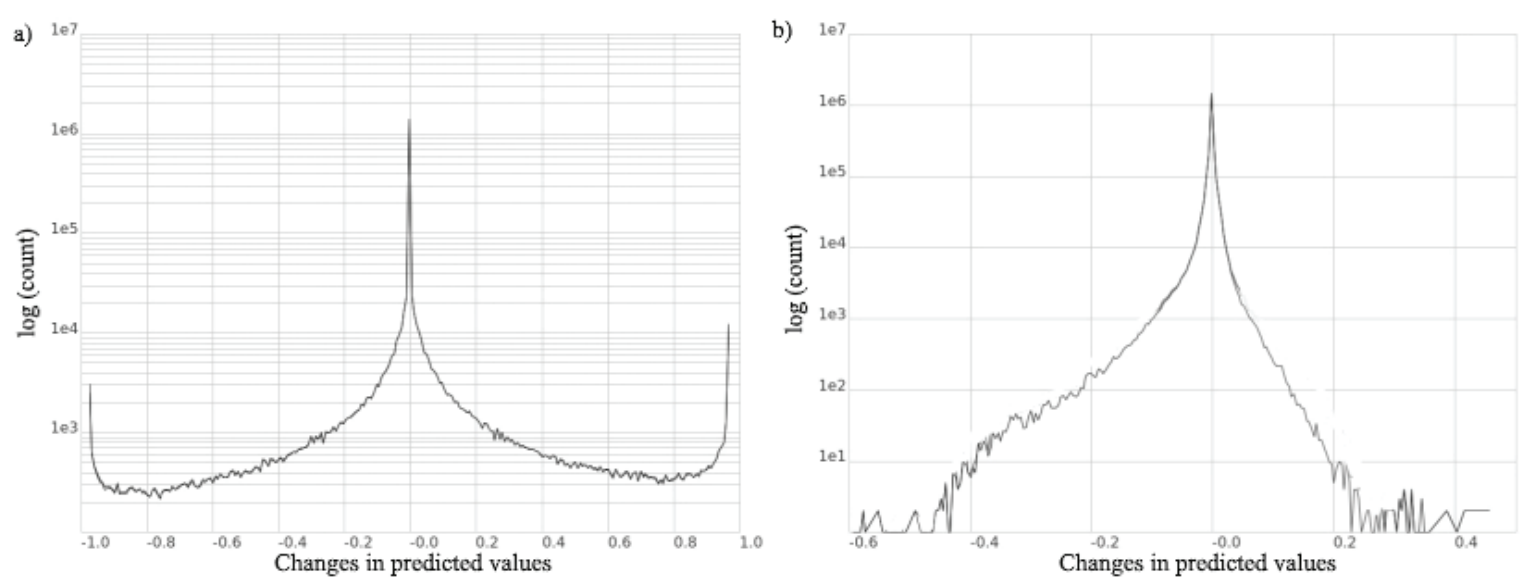

Figure 4. Histograms of changes in soil wetness predictions. 
The histograms also show that the methodology used in this study slightly changes the prediction of soil moisture (Figure 4). The absolute majority of values do not change, but a deviation is observed. For areas on glacigenic sediments, (a) there is a relatively large number of extreme values which indicate significant changes in the soil wetness predictions in one direction or the other. However, for the areas on glaciolimnic (b) sediments, there is a slight shift in predictions towards the wet side.

\section{Conclusions}

1. Soil wetness predictions for areas on glacigenic sediments is significantly influenced by local depressions. By modifying DEM with overlapping ditch vector data and changing elevation values in overlaying areas to null, many local depressions are eliminated, thus making soil wetness predictions to dry conditions.
2. For soils on glaciolimnic sediments, soil wetness predictions for the area close to ditches are leaning towards wet conditions, because local lowest elevations are eliminated and thus making other proximate areas as locally wet.

3. In some areas on glacigenic sediments soil wetness predictions are increasing because of slight horizontal shift between digitized ditch vectors and ditch locations in DEM.

4. There are no differences in soil moisture forecasts using different methodologies in areas with glaciofluvial and aeolian deposits.

\section{Acknowledgements}

The study is implemented within the scope of the project Demonstration of climate change mitigation measures in nutrients rich drained organic soils in the Baltic States and Finland LIFE OrgBalt, grant agreement No. LIFE18 CCM/LV/001158.

\section{References}

Cambi, M., Certini, G., Neri, F., \& Marchi, E. (2015). The impact of heavy traffic on forest soils: A review. Forest Ecology and Management, 338, 124-138. DOI: 10.1016/J.FORECO.2014.11.022.

Creed, I.F., Sanford, S.E., Beall, F.D., Molot, L.A., \& Dillon, P.J. (2003). Cryptic wetlands: integrating hidden wetlands in regression models of the export of dissolved organic carbon from forested landscapes. Hydrological Processes, 17(18), 3629-3648. DOI: 10.1002/hyp.1357.

Dehvari, A., \& Heck, R.J. (2013). Effect of LiDAR derived DEM resolution on terrain attributes, stream characterization and watershed delineation. International Journal of Agriculture and Crop Sciences, 6(13), 949-967. Retrieved March 10, 2020, from www.ijagcs.com.

Detenbeck, N.E., Galatowitsch, S.M., Atkinson, J., \& Ball, H. (1999). Evaluating perturbations and developing restoration strategies for inland wetlands in the Great Lakes basin. Wetlands, 19(4), 789-820. DOI: 10.1007/BF03161785.

Gregory, S.V., Swanson, F.J., McKee, W.A., \& Cummins, K.W. (1991). An Ecosystem Perspective of Riparian Zones. BioScience, 41(8), 540-551. DOI: 10.2307/1311607.

Ivanovs, J., \& Lupikis, A. (2018). Identification of wet areas in forest using remote sensing data. Agronomy Research, 16. DOI: 10.15159/AR.18.192.

Lidberg, W., Nilsson, M., Lundmark, T., \& Ågren, A.M. (2017). Evaluating preprocessing methods of digital elevation models for hydrological modelling. Hydrological Processes, 31(26), 4660-4668. DOI: 10.1002/ hyp. 11385.

McNabb, D.H., Startsev, A.D., \& Nguyen, H. (2001). Soil Wetness and Traffic Level Effects on Bulk Density and Air-Filled Porosity of Compacted Boreal Forest Soils. ResearchGate, 65(4). DOI: 10.2136/ sssaj2001.6541238x.

Meirons, Z. (2002). Quaternary sediments. M.:1:200 000. State Geological Survey.

Mohtashami, S., Eliasson, L., Jansson, G., \& Sonesson, J. (2017). Influence of soil type, cartographic depth-towater, road reinforcement and traffic intensity on rut formation in logging operations: A survey study in Sweden. Silva Fennica, 51(5). DOI: 10.14214/sf.2018.

Robson, A., Beven, K., \& Neal, C. (1992). Towards identifying sources of subsurface flow: A comparison of components identified by a physically based runoff model and those determined by chemical mixing techniques. Hydrological Processes, 6(2), 199-214. DOI: 10.1002/hyp.3360060208. 